\title{
Influence of salinity and water regime on tomato for processing
}

\author{
Vito Cantore, ${ }^{1}$ Bernardo Pace, ${ }^{1}$ Mladen Todorović, ${ }^{2}$ Egidio De Palma, ${ }^{1}$ Francesca Boari ${ }^{1}$ \\ ${ }^{1}$ Consiglio Nazionale delle Ricerche (CNR) - Istituto di Scienze delle Produzioni Alimentari, Bari; \\ ${ }^{2}$ CIHEAM - Istituto Agronomico Mediterraneo di Bari, Valenzano (BA), Italy
}

\begin{abstract}
The effects of salinity and watering regime on tomato crop are reported. The trials have been carried out over two years in southern Italy on a deep loam soil. Three saline levels of irrigation water (with electrical conductivity of $0.5,5$ and $10 \mathrm{dS} \mathrm{m}^{-1}$ ), three watering regimes (at 20\%, $40 \%$ and $60 \%$ of available water depletion), and two cultivars (HLY19 and Perfectpeel) were compared. The overall results related to the salinity tolerance are in agreement with those from the literature indicating that water salinity reduced marketable yield by $55 \%$ in respect to the control treatments. The irrigation regimes that provided higher total and marketable yield were at $40 \%$ and $60 \%$ of available water depletion (on average, 90.5 and $58.1 \mathrm{Mg} \mathrm{ha}^{-1}$ against 85.3 and $55.5 \mathrm{Mg} \mathrm{ha}^{-1}$ of the $20 \%$ available water depletion). Saline and irrigation treatments did not affect sunburned fruits, while affected incidence of fruits with blossom-end rot. The former disease appeared more dramatically in saline treatments $(+28 \%$ in respect to the control), and occurred mainly in HLY19. The disease incidence was by $52 \%$ lower in W2 respect to the W1 and W3. Fruit firmness was higher in S0, whereas it was not affected by irrigation regimes. Total soluble solids and dry matter content of tomato fruits were increased by salinity, whereas it was not affected by irrigation regimes and cultivars. The $\mathrm{pH}$ and the titratable acidity remained unchanged between the years, the cultivar and the saline and irrigation treatments. Similarly to the last parameters, the fruit ascorbic acid content remained unchanged in relation to the treatments, but it was higher in HLY19.
\end{abstract}

The recommended thresholds of easily available water to preserve

Correspondence: Dr. Bernardo Pace, Consiglio Nazionale delle Ricerche (CNR) - Istituto di Scienze delle Produzioni Alimentari, via Amendola 122/0, 70126 Bari, Italy. Tel. +39.080 .5929310 - Fax: +39.080 .5929373 .

E-mail: bernardo.pace@ispa.cnr.it

Key words: brackish water, irrigation, Solanum lycopersicum, yield.

Acknowledgements: this research was funded by CLIMESCO Evolution of cropping systems as affected by climate change project, contract n. 285, 20/02/2006 (Ministry for Education, University and Research).

Received for publication: 5 April 2011.

Accepted for publication: 16 December 2011.

() Copyright V. Cantore et al., 2012

Licensee PAGEPress, Italy

Italian Journal of Agronomy 2012; 7:e10

doi:10.4081/ija.2012.e10

This article is distributed under the terms of the Creative Commons Attribution Noncommercial License (by-nc 3.0) which permits any noncommercial use, distribution, and reproduction in any medium, provided the original author(s) and source are credited. total and marketable yield were at $40 \%$ and $60 \%$, respectively. Watering more frequently, instead, on the soil type of the trial, probably caused water-logging and root hypoxia affecting negatively yield.

\section{Introduction}

Irrigated agriculture is dependent on adequate water supply and its quality. Water used for irrigation can vary greatly in quality, depending upon type and quantity of dissolved salts. They originate from dissolution or weathering of the rocks and soils, and by intrusion of seawater into the river and underground water resources (Selvaggi et al., 2010).

The European Environment Agency has recognized that the problem of saltwater intrusion due to groundwater over-exploitation is one of the major threats to coastal area freshwater resources in Europe (Scheidleger et al., 2004; Rapti-Caputo, 2010). Italy has been indicated as one of the countries where the problem is felt most severely (Cau et al., 2002; Barrocu, 2003; Scheidleger et al., 2004; Capaccioni et al., 2005) with several hot-spot areas in Apulia region (Cotecchia and Polemio, 1997; Polemio and Limoni, 2001; Ancona et al., 2010).

In many irrigated areas, especially in the zones characterized by intensive agricultural activities, dwindling supplies of quality water for irrigation and increasing demand from other users are forcing farmers to use saline irrigation waters (Rhoades, 1987; Rhoades et al., 1992; Shani and Dudley, 2001). In the case of irrigation, the salts are applied with the water and remain behind in the soil, as water evaporates or it is used by the crop, contributing to soil salinization. This can lead to the acceleration of desertification process with increasing salt concentration in the top soil layers and negative effect on plant growth and productivity.

Saline soil water inhibits plant growth for an osmotic effect, which reduces the ability of the plant to take up water, and by ion excess which affects the plant cells (Yeo et al., 1991; Munns, 2002; 2005). Soil salinity also induces reduced plant growth due to specific ion toxicities (e.g., $\mathrm{Na}^{+}$and $\mathrm{Cl}^{-}$) and ionic imbalances acting on biophysical and/or metabolic components of plant growth (Grattan and Grieve, 1999). When salinity is due to sodium salts, it can lead to the formation of sodic soils where salts are leached from the soil profile.

In many cases, salinity can lead to waterlogged soils and these two negative interactions between hypoxia and salts have a powerful depressive effect on plant growth (Barrett-Lennard, 2003). Under saline conditions, many plants are able to compensate partially low osmotic potential of soil water by building up higher internal solute contents. This is done by absorbing ions from the soil solution and by synthesizing organic osmolytes. Both of these reactions reduce the impact of osmotic potential on water availability (Allen et al., 1998).

When saline waters are used for irrigation, attention should be given to minimize root-zone salinity (Shani and Dudley, 2001; Gideon et al., 2002; Katerji et al., 2003), using appropriate irrigation systems and practices that will supply just sufficient quantity of water to the root-zone to meet the evaporative demand and minimize salt accumu- 
lation in the root-zone (Fisher, 1980; Munns, 2002). Irrigation frequency has stated the most important factor in crop management using saline irrigation (Pereira et al., 2009). In fact, generally saline water requires more frequent irrigation than fresh water because salts in the water and in the soil increase the osmotic potential of soil water, which makes water uptake by the crop roots more difficult.

The threshold value above which deleterious effects occur can vary depending on several factors including plant type, soil water regime and climatic condition (Maas, 1986). In rainfed agriculture soil water can be far below field capacity and the salt concentration several-fold higher than measured at soil saturation water content (Rengasamy, 2002). Tomato for processing industry is among common open field crops cultivated in Southern Italy with a high economical impact. This species is often cultivated in soils affected by salinity problems and/or irrigated with saline water.

Experimental results indicate tomato as a salt moderately sensitive crop (Flagella et al., 2002) according to Mass and Hoffman (1977) model, and stressed also negative effects of salinity on absorption and translocation of $\mathrm{Ca}^{++}$(Grattan and Grieve, 1999) that is easily connected to the blossom-end rot (Adams and Ho, 1992; Belda and Ho, 1993; Max and Horst, 2009).

The soil water regime is a remarkable factor that affect tomato yield in saline conditions. As known, the water depletion fraction threshold is a specific characteristic and for tomato crop this parameter is equivalent to $40 \%$ (Allen et al., 1998). However, to compensate the higher osmotic pressure that happened in saline conditions, it is necessary to increase soil water potential; for this reason, the threshold of water depletion fraction can change.

For tomato crop, literature data showing the optimal water depletion fraction in saline conditions are not available. Therefore, the aim of this work is to evaluate the best watering regime in relation to the salinity.

\section{Materials and methods}

\section{Experimental site and climate}

The research was carried out during 2007 and 2009 summer period at the experimental farm Enrico Pantanelli of Bari's University and located in Policoro (MT, southern Italy; $\left.40^{\circ} 10^{\prime} 20^{\prime \prime} \mathrm{N}, 16^{\circ} 39^{\prime} 04^{\prime \prime} \mathrm{E}\right)$. This site is $15 \mathrm{~m}$ above sea level and is characterized by sub-humid climate according to De Martonne classification (Cantore et al., 1987), with average annual rainfall of $560 \mathrm{~mm}$ distributed mainly during autumn and winter, and with maximum temperature reaching $40-42^{\circ} \mathrm{C}$ in the summer.

The soil, more than $1.2 \mathrm{~m}$ deep, was a loam. Physical and chemical characteristics of the soil were: sand $(2>\emptyset>0.02 \mathrm{~mm}) 40 \%$, silt $37.1 \%$, clay $(\emptyset<2 \mu) 22.9 \%$; $\mathrm{pH} 7.7$; total $\mathrm{N}$ (Kjeldahl method) $1.67 \mathrm{~g} \mathrm{~kg}^{-1}$, available $\mathrm{P}_{2} \mathrm{O}_{5}$ (Olsen method) $26.7 \mathrm{mg} \mathrm{kg}^{-1}$, exchangeable $\mathrm{K}_{2} \mathrm{O}$ (ammonium acetate method) $227 \mathrm{mg} \mathrm{kg}^{-1}$, organic matter (Walkley-Black method) $36.4 \mathrm{~g} \mathrm{~kg}^{-1}$, total limestone $15.0 \mathrm{~g} \mathrm{~kg}^{-1}$, active limestone $5.0 \mathrm{~g} \mathrm{~kg}^{-1}$; saturated paste extract electrical conductivity (ECe) $0.95 \mathrm{dS} \mathrm{m}^{-1}$, ESP $1.9 \%$; bulk density $1.25 \mathrm{~kg} \mathrm{dm}^{-3}$; soil moisture at field capacity (measured in situ) $31.5 \%$ and at wilting point (-1.5 MPa) $15 \%$ of soil dry weight.

\section{Treatments and cultural practices}

Two tomato (Solanum lycopersicum L.) cultivars, HLY 19 (Hazera Genetics Ltd, Brurim Israel, for Italy COIS' $94^{\circledR}$ S.p.A., Catania) and Perfectpeel (Seminis Vegetable Seeds, Parma, Italy) were irrigated with water having three salinity levels (S0, S1 and S2) of electrical conductivity $\left(\mathrm{EC}_{\mathrm{w}}\right)$ corresponding to 0.5 (i.e. control), 5 and $10 \mathrm{dS} \mathrm{m}$ - 1 , respec- tively, and applying three irrigation regimes (W1, W2 and W3) with management allowable depletion 20,40 and $60 \%$ of available water depletion, respectively. The two saline waters (S1 and S2) were obtained by adding sea salt to the fresh water. A split plot experimental design with three replicates was established with salinity levels as main factor and the cultivars in the sub-sub plots $15 \mathrm{~m}^{2}$ large. Tomato seedlings were transplanted at three true leaves stage on June $5^{\text {th }}$ and May $12^{\text {th }}$ in 2007 and 2008 , respectively. Plant density was 2.7 plants $\mathrm{m}^{-2}$ in single rows spaced, $1.50 \mathrm{~m}$ between rows and $0.25 \mathrm{~m}$ between the plants along the row. Along the rows a black PVC mulching was applied. The soil was fertilized before transplanting with 80 and $100 \mathrm{~kg}$ $\mathrm{ha}^{-1}$ of $\mathrm{N}$ and $\mathrm{P}_{2} \mathrm{O}_{5}$, respectively. The irrigation was performed by polyethylene drip tubing method, placing one pipeline for each row under the mulching, when water lost by evapotranspiration (ETc) reached the 20 (W1), 40 (W2) and 60\% (W3) of available water depletion in the soil layer explored by roots, with a watering volume able to restore $100 \%$ of water lost. The ETc was calculated by evopotranspirometric method, utilizing daily values of class A pan evaporation, pan coefficient equal to 0.8 (Castrignanò et al., 1985), and the crop coefficients reported by Tarantino and Caliandro (1984), adjusted for saline treatments (Allen et al., 1998). The irrigation was cut off 22-24 days before harvest (on August $29^{\text {th }} 2007$ and on August $4^{\text {th }} 2008$ ), according to farmers practice to improve fruits quality in terms of total soluble solids and dry matter content of fruits.

Phytosanitary control was performed by integrated pest management strategies. Moreover, weed control was performed by a mechanical hoeing in the inter-row and by hand the weeds emerged from the hole of the plastic mulch.

\section{Climatic parameters}

The main climatic parameters, including solar radiation, air temperature, relative humidity, wind speed, class $A$ pan evaporation and rainfall, were provided by a standard weather station located about $50 \mathrm{~m}$ from the experimental field and equipped with a pyranometer (model CM 4, Kipp and Zonen, Delft, The Netherlands), thermistor (model E001, Tecno.El, Roma, Italy), hygrometer (C-83_N Rotronic, Zurich, Switzerland), anemometer (model VT 0805B, SIAP Bologna, Villanova di Castelnaso, B0, Italy), class A pan (NovaLynx Corporation Grass Valley, Auburn, CA, USA), and tipping bucket rain gauge (Tecno.El). The weather data were collected by the electronic system operated through a data-logger (model Kampus, Tecno.El) connected via modem to a PC.

\section{Soil moisture and salinity}

Monthly, in the S1 salinity treatment of each irrigation treatment, the moisture of 0-0.6 m deep soil layer was measured by gravimetric method in three places per plot, crosswise to the row at $0-0.25-0.5 \mathrm{~m}$ from the emitters.

The ECe was measured in the laboratory, on the soil samples collected through a cylindrical probe $(\varnothing 2.5 \mathrm{~cm})$ from $0-0.6 \mathrm{~m}$ soil layer in three places per plot, crosswise to the row at $0-0.25-0.50 \mathrm{~m}$ from the emitters. The measures were made at beginning, in the middle and at the end of crop cycle in S0 and S2 salinity levels and in W1 and W3 irrigation regimes.

\section{Yield and quality}

Harvest took place by hand on September $20^{\text {th }} 2007$ and on August $28^{\text {th }}-30^{\text {th }} 2008$. The total, marketable and unmarketable (including green, blossom-end rot, cracked, green shoulder, and fruits damaged by viruses and/or pests) yields were determined.

A sample of 2-3 kg of product was taken to assess the percentage of fruits with blossom-end rot, sunburn, pest and virus attacks. On the marketable fruits, firmness, dry biomass, total soluble solids, titratable acidity, $\mathrm{pH}$, 
ascorbic acid content and the morphological parameters including the mean weigh and the shape index were measured. The mean weight was calculated on a sample of $4-5 \mathrm{~kg}$ of fruits. The dry matter content was assessed by splitting a sample of 5-6 fruits and placing it in a ventilated oven at the temperature of $55^{\circ} \mathrm{C}$ till a constant weight was reached (about 48 hrs). The total soluble solids, the titratable acidity and the ascorbic acid content were determined on the sauce (using about $2 \mathrm{~kg}$ of fruits) obtained by liquefying fruit in a blender ( $1 \mathrm{~min} ; 14,000 \mathrm{rev} \cdot \mathrm{min}^{-1}$ ) and then filtering all mesocarp; from a well-homogenised sauce three samples were taken for each parameter to test. Total soluble solid (TSS) content in juice was determined using a refractometer (model DBR35, XS Instruments, Poncarale, $\mathrm{BS}$, Italy) and expressed as ${ }^{\circ} \mathrm{Brix}$ at $20^{\circ} \mathrm{C}$. Acidity was determined by titrating $\mathrm{NaOH} 0.1 \mathrm{M}$ in the presence of phenolphthalein with an automatic titrating machine (Technotrate, Kartell, Noviglio, MI, Italy) until color change with the result expressed in terms of monohydrate acid. Fruit juice $\mathrm{pH}$ was measured using a $\mathrm{pH}$ meter (Acorn $\mathrm{pH} 6$ Meter, Oakton Instruments, Vernon Hills, IL, USA). Ascorbic acid content was assessed with a RQflex 2 Reflectoquant ${ }^{\circledR}$ system (Merck KGaA, Darmstadt, Germany). Fruit firmness was measured on a sample of ten fruits after the skin peeling ( $1 \mathrm{~mm}$ thick); in particular, two measures were carried out at equatorial level utilizing a digital fruit firmness tester (model 53205 TR, Turoni, Forlì, FC, Italy) with a point of $3 \mathrm{~mm}$ of diameter.

\section{Statistical analysis}

Analysis of variance of the treatment effects on measured traits was performed using the SPSS Software package; the differences between means were analyzed with the Student-Newman-Keuls test.

\section{Results and discussion}

\section{Climatic trend}

In 2007, the climatic conditions during the growing season were very dry (Figure 1). The total amount of rainfall $(20 \mathrm{~mm})$ occurred almost all in the first week after planting. Daily minimum temperature (Tmin) ranged between 9.5 and $29.5^{\circ} \mathrm{C}$ : the lower value occurred at the end of crop cycle and the higher on August $9^{\text {th }}$, during the fruit enlargement stage. Tmin was lower than $20^{\circ} \mathrm{C}$ until June $20^{\text {th }}$; after this date it was almost always higher than $20^{\circ} \mathrm{C}$ until the end of August.

Daily maximum temperature (Tmax) ranged between 21.5 and $41.5^{\circ} \mathrm{C}$. In the period between the middle of June and the end of August it was almost always higher than $30^{\circ} \mathrm{C}$. Very hot days $\left(\operatorname{Tmax}>40^{\circ} \mathrm{C}\right.$ ) occurred on June $24^{\text {th }}$ and 25 , July $24^{\text {th }}$ and August $26^{\text {th }}$ (Figure 1).

Also in 2008, the growing season of tomato was characterized by very dry climate. The total rainfall was $54 \mathrm{~mm}$, the $80 \%$ of which occurred in the 1st decade of June. Tmin ranged between 12 and $29^{\circ} \mathrm{C}$. The lower value occurred at beginning of crop cycle and the higher one on July $3^{\text {rd }}$, at fruit enlargement stage. Until June $10^{\text {th }}$, Tmin was lower than $20^{\circ} \mathrm{C}$, afterwards it was almost always higher than $20^{\circ} \mathrm{C}$. Tmax ranged between 20 and $40^{\circ} \mathrm{C}$. After the middle of June it exceeded $32^{\circ} \mathrm{C}$ with the hottest days $\left(38-40^{\circ} \mathrm{C}\right)$ occurring on July $8^{\text {th }}$ and $15^{\text {th }}$ (Figure 1 ).

\section{Soil salinity}

In both years, ECe in the control treatment (S0) remained stationary with values ranging around $1.2 \mathrm{dS} \mathrm{m} \mathrm{m}^{-1}$, whereas it increased in S2 treatment as a consequence of salts distributed by irrigation (Figure 2). In the former salinity treatment, ECe increased from 1.7 to $10.6 \mathrm{dS}$ $\mathrm{m}^{-1}$ and from 1.7 to $12.3 \mathrm{dS} \mathrm{m}^{-1}$ of S2W1, from 1.7 to $13.4 \mathrm{dS} \mathrm{m}^{-1}$ and from 1.8 to $12.1 \mathrm{dS} \mathrm{m}^{-1}$ of S2W3, in the $1^{\text {st }}$ and $2^{\text {nd }}$ year, respectively. The ECe mean of the whole crop cycle ranged from 1.6 to 7.9 and from 1.7 to $8.5 \mathrm{dS} \mathrm{m}^{-1}$, in the $1^{\text {st }}$ and $2^{\text {nd }}$ year, respectively (Table 1 ).

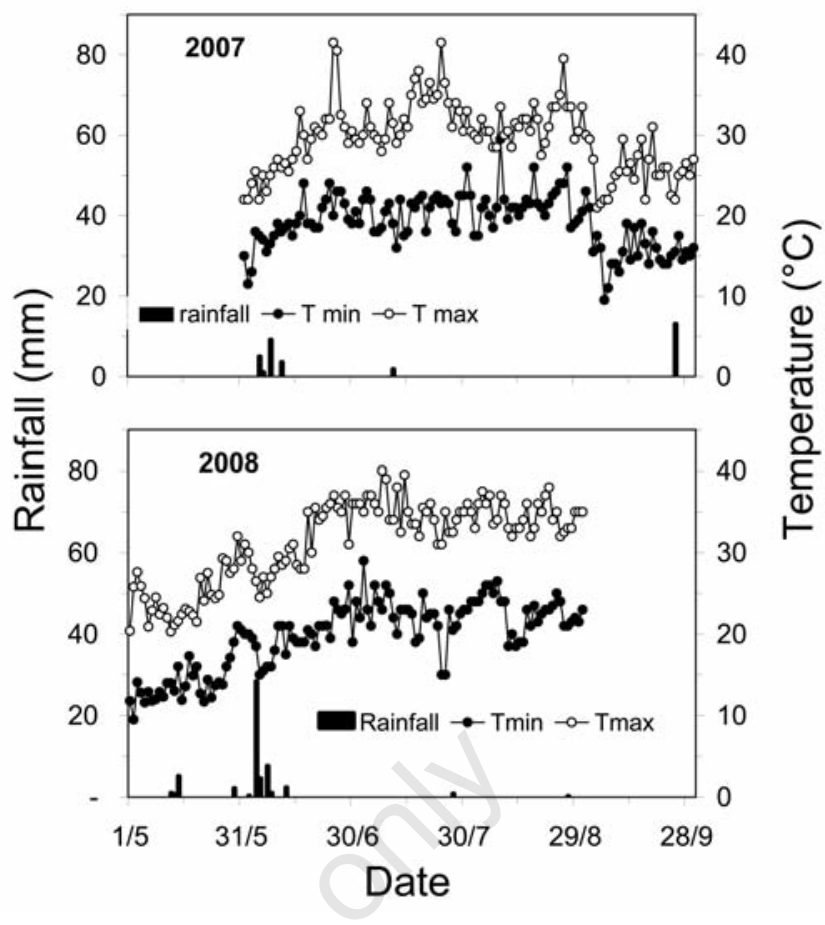

Figure 1. Daily rainfall, minimum (Tmin) and maximum (Tmax) temperature during the two crop cycles of tomato.

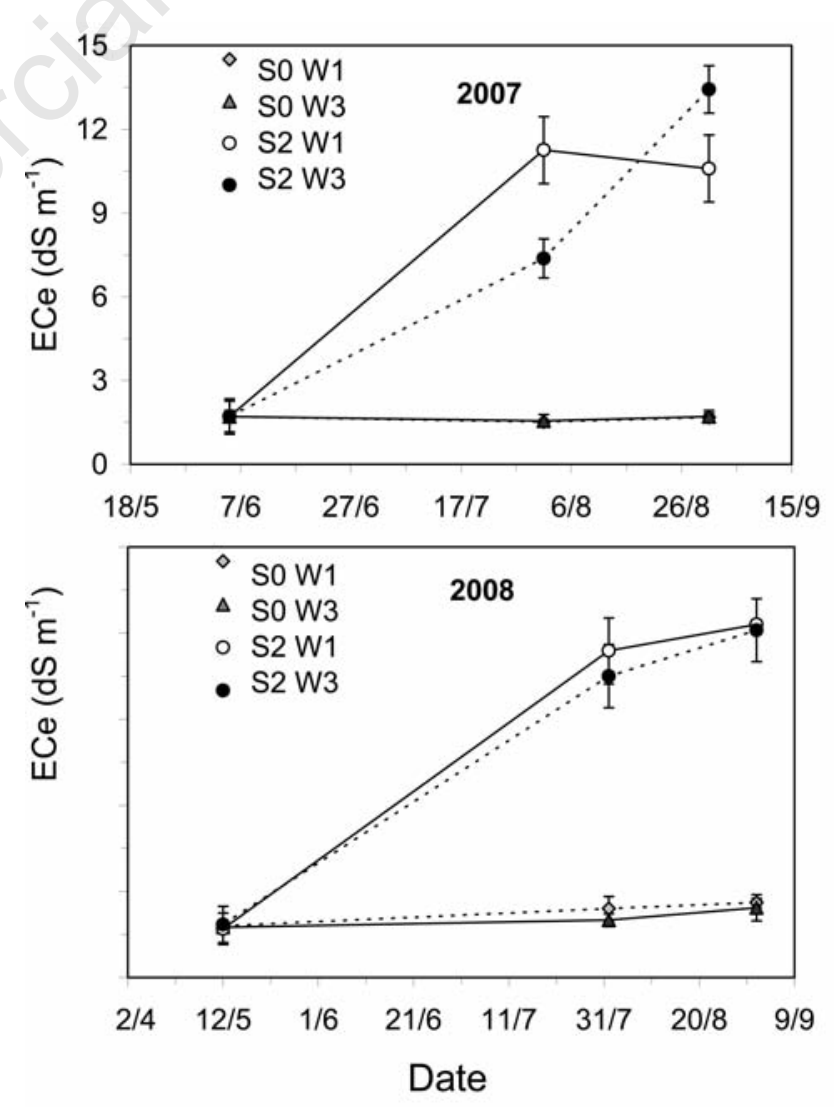

Figure 2. Soil ECe in the two salinity treatments (S0 and S2) and two irrigation regimes (W1 and W3) of the layer 0-0.6 m deep, during the tomato crop cycle. Each value represents the average between three distances from the emitter $(0,0.25$ and $0.5 \mathrm{~m})$ and three replicates. Vertical bars shown \pm SD. 


\section{Yield and quality}

Marketable yield was 24\% higher in 2008 in respect to 2007 whereas total yield remained unchanged (Table 2). Salinity and irrigation regimes treatments affected tomato yield. Total and marketable yield decreased respectively by 49 and $55 \%$ between $\mathrm{S} 0$ and S2. The irrigation regimes that provided higher total and marketable yield were W2 and W3 (on average, 90.5 and $58.1 \mathrm{Mg} \mathrm{ha}^{-1}$ against 85.3 and $55.5 \mathrm{Mg}$ $\mathrm{ha}^{-1}$ of W1).

Saline and irrigation treatments did not affect sunburned fruits, while affected incidence of fruits with blossom-end rot (BER) (Table $2)$. The former disease appeared more dramatically in saline treatments (+28\%) respect to the control, mainly in $H L Y 19$ that is a cultivar with elongated fruits. Moreover, the disease incidence was by $52 \%$ lower in W2 in respect to W1 and W3. These results are in agreement with the literature data. The blossom-end rot is related to the ionic imbalances caused by $\mathrm{Na}^{+} / \mathrm{Ca}^{2+}$ competition (Grattan and Grieve, 1999). This disease, occurring more frequently in the tomato cultivar with elongated fruits (Adams and Ho, 1992; 1995; Belda and Ho, 1993; Cantore et al., 2008), apart from the high environmental evaporative demand (Adams and Ho, 1993; Ho and White, 2005), is favoured by water and/or saline stress (Adams and Ho, 1992; Max and Horst, 2009). Higher incidence of BER, happened in W1 and W3, is ascribed to i) tem-

Table 1. ECe \pm SD, mean of crop cycle of different salinity and water regime treatments, in two experimental years.

\begin{tabular}{lcc} 
Treatments & Years \\
& 2007 & 2008 \\
S0 W1 & $1.64 \pm 0.12$ & $2.27 \pm 0.15$ \\
S0 W3 & $1.66 \pm 0.84$ & $2.06 \pm 0.68$ \\
\hline S2 W1 & $7.85 \pm 1.00$ & $8.46 \pm 1.15$ \\
S2 W3 & $7.50 \pm 1.36$ & $8.15 \pm 0.99$ \\
\hline
\end{tabular}

porary conditions of root asphyxia for $\mathrm{W} 1$, that occurred because of frequent watering and consequent water and nutritional imbalance; ii) short periods of water stress because of less frequent watering and greater allowable depletion for W3.

Yield decrease caused by salinity is ascribed mainly by the fruit weight decrease. In fact, the salt stressed tomato reduces yield initially through the lowering of fruit size and then decreasing their number (van Ieperen, 1996; Cuartero and Soria, 1997).

Moreover, reporting the relative marketable yield values vs the soil ECe mean for the whole crop cycle, we can conclude that these values are in agreement with the Maas and Hoffman (1977) model of tomato as reported by Francois and Maas (1994). In fact, tomato crop is moderately sensitive to salinity with the ECe threshold equal to $2.5 \mathrm{dS} \mathrm{m}^{-1}$ and slope of $9.9 \% \mathrm{dS}^{-1} \mathrm{~m}$ (Maas, 1986). Instead, salinity tolerance can change related to the plant intrinsic factors (cultivar), or external factors (soil and climatic conditions) related to phenological stage and the length of salt stress (Ehret and Ho, 1986; Adams, 1986; van Ieperen, 1996).

Shape index was different for two cultivars (2.1 for $H L Y 19$ and 1.2 for Perfectpeel) as expected and lasted unchanged in relation to the saline and irrigation treatments. Fruit firmness was higher in 2008, in $H L Y 19$ and in S0, whereas it was not affected by irrigation regimes (Table 3 ). Total soluble solids and dry matter content of tomato fruits were higher in 2007 and were enhanced by increasing salinity level, whereas they were not affected by irrigation regimes and cultivar (Table 4).

The results confirmed that the use of brackish water improve tomato quality traits as total soluble solids and dry matter (Mizrahi and Pasternak, 1985; Plaut, 1997; Cucci et al., 2000; Cantore et al. 2001; Incerti et al., 2007; Magàn et al., 2008; Wu and Kubota, 2008; Segura et al., 2009) and reduce firmness (Sharaf and Hobson, 1986). The pH and the titratable acidity remained unchanged in two experimental years, for different cultivars and saline and irrigation treatments. Similarly to the last parameters, fruit ascorbic acid content remained unchanged in relation to the treatments, but it was higher in HLY19.

Table 2. Yield and damaged tomato fruits by blossom-end rot and sunscald for different years, salinity levels, irrigation regimes and cultivars.

\begin{tabular}{|c|c|c|c|c|}
\hline O & $\begin{array}{c}\text { Total } \\
\left(\mathrm{Mg} \mathrm{ha}^{-1}\right)\end{array}$ & $\begin{array}{c}\text { Marketable } \\
\left(\mathrm{Mg} \mathrm{ha}^{-1}\right)\end{array}$ & $\begin{array}{l}\text { Blossom end rot } \\
(\%)\end{array}$ & $\begin{array}{c}\text { Sunscald } \\
(\%)\end{array}$ \\
\hline \multicolumn{5}{|l|}{ Years } \\
\hline $\begin{array}{l}2007 \\
2008\end{array}$ & $\begin{array}{l}87.8 \\
89.6\end{array}$ & $\begin{array}{l}51.0^{\mathrm{b}} \\
63.5^{\mathrm{a}}\end{array}$ & $\begin{array}{l}2.3^{\mathrm{b}} \\
3.6^{\mathrm{a}}\end{array}$ & $\begin{array}{l}3.0^{\mathrm{a}} \\
2.3^{\mathrm{b}}\end{array}$ \\
\hline $\begin{array}{l}\text { Salinity } \\
\text { S0 } \\
\text { S1 } \\
\text { S2 }\end{array}$ & $\begin{array}{l}121.5^{\mathrm{a}} \\
82.5^{\mathrm{b}} \\
62.1^{\mathrm{c}}\end{array}$ & $\begin{array}{l}82.2^{\mathrm{a}} \\
52.4^{\mathrm{b}} \\
37.1^{\mathrm{c}}\end{array}$ & $\begin{array}{l}2.5^{\mathrm{b}} \\
3.2^{\mathrm{a}} \\
3.2^{\mathrm{a}}\end{array}$ & $\begin{array}{l}2.7 \\
2.9 \\
2.4\end{array}$ \\
\hline \multicolumn{5}{|l|}{ Irrigation regime } \\
\hline $\begin{array}{l}\text { W1 } \\
\text { W2 } \\
\text { W3 }\end{array}$ & $\begin{array}{l}85.3^{\mathrm{b}} \\
91.7^{\mathrm{a}} \\
89.2^{\mathrm{a}}\end{array}$ & $\begin{array}{l}55.5^{\mathrm{b}} \\
59.0^{\mathrm{a}} \\
57.2^{\mathrm{a}}\end{array}$ & $\begin{array}{l}3.2^{\mathrm{a}} \\
1.7^{\mathrm{b}} \\
3.9^{\mathrm{a}}\end{array}$ & $\begin{array}{l}2.6 \\
2.5 \\
2.8\end{array}$ \\
\hline $\begin{array}{l}\text { Cultivar } \\
\text { HLY19 } \\
\text { Perfectpeel }\end{array}$ & $\begin{array}{l}81.1^{\mathrm{b}} \\
96.4^{\mathrm{a}}\end{array}$ & $\begin{array}{l}51.0^{\mathrm{b}} \\
63.4^{\mathrm{a}}\end{array}$ & $\begin{array}{l}4.9^{\mathrm{a}} \\
1.1^{\mathrm{b}}\end{array}$ & $\begin{array}{l}2.2^{\mathrm{b}} \\
3.1^{\mathrm{a}}\end{array}$ \\
\hline $\begin{array}{l}\text { Significance } \\
\text { Y } \\
\text { S } \\
\text { IR } \\
\text { C } \\
\text { Interactions (Y.S; Y.IR; Y.C; S.IR; S.C; IR.C; Y.S.IR.C) }\end{array}$ & $\begin{array}{l}\mathrm{ns} \\
* * \\
* \\
* * \\
\mathrm{~ns}\end{array}$ & $\begin{array}{l}* \\
* * \\
* \\
* * \\
\text { ns }\end{array}$ & $\begin{array}{l}* \\
* \\
* \\
* * \\
\text { ns }\end{array}$ & $\begin{array}{c}* \\
\mathrm{~ns} \\
\mathrm{~ns} \\
* \\
\mathrm{~ns}\end{array}$ \\
\hline
\end{tabular}


Table 3. Morphological characteristics of tomato fruits for different years, salinity levels, irrigation regimes and cultivars.

\begin{tabular}{|c|c|c|c|c|c|}
\hline Treatments & $\begin{array}{l}\text { Mean weight } \\
\text { (g) }\end{array}$ & $\begin{array}{l}\text { Length (a) } \\
\text { (mm) }\end{array}$ & $\begin{array}{l}\text { Width (b) } \\
(\mathrm{mm})\end{array}$ & $\begin{array}{l}\text { Shape index } \\
\qquad\left(\mathbf{a ~ b}^{-1}\right)\end{array}$ & $\begin{array}{l}\text { Firmness } \\
\left(\mathrm{kg} \mathrm{cm}^{-2}\right)\end{array}$ \\
\hline $\begin{array}{l}\text { Years } \\
2007 \\
2008\end{array}$ & $\begin{array}{l}54.2 \\
52.9\end{array}$ & $\begin{array}{l}62.3^{\mathrm{a}} \\
45.0^{\mathrm{b}}\end{array}$ & $\begin{array}{l}44.7^{\mathrm{a}} \\
25.4^{\mathrm{b}}\end{array}$ & $\begin{array}{l}1.4 \mathrm{~b} \\
1.8 \mathrm{a}\end{array}$ & $\begin{array}{l}4.4^{\mathrm{b}} \\
5.1^{\mathrm{a}}\end{array}$ \\
\hline $\begin{array}{l}\text { Salinity } \\
\text { S0 } \\
\text { S1 } \\
\text { S2 }\end{array}$ & $\begin{array}{l}65.9^{\mathrm{a}} \\
53.8^{\mathrm{b}} \\
41.1^{\mathrm{c}}\end{array}$ & $\begin{array}{l}58.5^{\mathrm{a}} \\
54.2^{\mathrm{b}} \\
48.3^{\mathrm{c}}\end{array}$ & $\begin{array}{c}38.4^{\mathrm{a}} \\
35.5^{\mathrm{ab}} \\
31.3^{\mathrm{b}}\end{array}$ & $\begin{array}{l}1.6 \\
1.6 \\
1.7 \\
\end{array}$ & $\begin{array}{l}5.2^{\mathrm{a}} \\
4.7^{\mathrm{ab}} \\
4.4^{\mathrm{b}}\end{array}$ \\
\hline $\begin{array}{l}\text { Irrigation regime } \\
\text { W1 } \\
\text { W2 } \\
\text { W3 }\end{array}$ & $\begin{array}{l}52.7^{\mathrm{b}} \\
57.0^{\mathrm{a}} \\
51.1^{\mathrm{b}}\end{array}$ & $\begin{array}{l}52.9^{\mathrm{b}} \\
56.2^{\mathrm{a}} \\
51.9^{\mathrm{b}}\end{array}$ & $\begin{array}{l}35.3 \\
35.3 \\
34.5\end{array}$ & $\begin{array}{l}1.6 \\
1.7 \\
1.6\end{array}$ & $\begin{array}{l}4.9 \\
4.7 \\
4.7\end{array}$ \\
\hline $\begin{array}{l}\text { Cultivar } \\
\text { HLY19 } \\
\text { Perfectpeel }\end{array}$ & $\begin{array}{l}51.0^{\mathrm{b}} \\
56.2^{\mathrm{a}}\end{array}$ & $\begin{array}{l}61.1^{\mathrm{a}} \\
46.2^{\mathrm{b}}\end{array}$ & $\begin{array}{l}30.5^{\mathrm{b}} \\
39.6^{\mathrm{a}}\end{array}$ & $\begin{array}{l}2.1^{\mathrm{a}} \\
1.2^{\mathrm{b}}\end{array}$ & $\begin{array}{l}5.4^{\mathrm{a}} \\
4.2^{\mathrm{b}}\end{array}$ \\
\hline $\begin{array}{l}\text { Significance } \\
\text { Y } \\
\text { S } \\
\text { IR } \\
\text { C } \\
\text { Interactions (Y.S; Y.IR; Y.C; S.IR; S.C; IR.C; Y.S.IR.C) }\end{array}$ & $\begin{array}{l}\mathrm{ns} \\
* * \\
* \\
* \\
\mathrm{~ns}\end{array}$ & $\begin{array}{c}* \\
* \\
* \\
* \\
* \\
\text { ns }\end{array}$ & $\begin{array}{c}* \\
* \\
\text { ns } \\
* \\
\text { ns }\end{array}$ & $\begin{array}{l}* \\
\text { ns } \\
\text { ns } \\
* * \\
\text { ns }\end{array}$ & $\begin{array}{c}* \\
* \\
\text { ns } \\
* \\
\text { ns }\end{array}$ \\
\hline
\end{tabular}

Table 4. Quality characteristics of tomato fruits for different years, salinity levels, irrigation regimes and cultivars.

\begin{tabular}{|c|c|c|c|c|c|}
\hline Treatments & $\begin{array}{l}\text { soluble solids } \\
\left({ }^{\circ} \text { Brix) }\right.\end{array}$ & $\begin{array}{l}\text { Ascorbic acid } \\
\text { (mg } 100 \mathrm{~mL}^{-1} \\
\text { juice) }\end{array}$ & $\begin{array}{l}\text { Titratable acidity } \\
\text { (g citric acid } 100 \mathrm{~mL}^{-1} \\
\text { juice) }\end{array}$ & $\mathrm{pH}$ & $\begin{array}{l}\text { Dry matter } \\
\left(\mathrm{g} 100 \mathrm{~g}^{-1} \mathrm{fw}\right)\end{array}$ \\
\hline \multicolumn{6}{|l|}{ Years } \\
\hline 2007 & $7.0^{\mathrm{a}}$ & 28.3 & 0.3 & 4.4 & $8.0^{a}$ \\
\hline 2008 & $5.4^{\mathrm{b}}$ & 29.5 & 0.3 & 4.6 & $6.4^{\mathrm{b}}$ \\
\hline \multicolumn{6}{|l|}{ Salinity } \\
\hline SO & $5.7^{\mathrm{b}}$ & 29.4 & 0.3 & 4.5 & $6.6^{\mathrm{b}}$ \\
\hline S1 & $6.2^{\mathrm{a}}$ & 29.0 & 0.3 & 4.5 & $7.3^{\mathrm{a}}$ \\
\hline S2 & $6.7^{\mathrm{a}}$ & 28.4 & 0.3 & 4.5 & $7.7^{\mathrm{a}}$ \\
\hline \multicolumn{6}{|l|}{ Irrigation regime } \\
\hline W1 & 6.2 & 30.2 & 0.3 & 4.5 & 7.2 \\
\hline W2 & 6.3 & 28.0 & 0.3 & 4.4 & 7.2 \\
\hline W3 & 6.2 & 28.6 & 0.3 & 4.5 & 7.1 \\
\hline \multicolumn{6}{|l|}{ Cultivar } \\
\hline HLY19 & 6.4 & $34.0^{\mathrm{a}}$ & 0.3 & 4.5 & 7.3 \\
\hline Perfectpeel & 6.0 & $23.8^{\mathrm{b}}$ & 0.3 & 4.4 & 7.1 \\
\hline \multicolumn{6}{|l|}{ Significance } \\
\hline $\mathrm{Y}$ & $*$ & ns & ns & ns & $*$ \\
\hline S & $* *$ & ns & ns & ns & $* *$ \\
\hline IR & ns & ns & ns & ns & ns \\
\hline $\mathrm{C}$ & ns & $*$ & ns & ns & ns \\
\hline Interactions (Y.S; Y.IR; Y.C; S.IR; S.C; IR.C; Y.S.IR.C) & ns & ns & ns & ns & ns \\
\hline
\end{tabular}

Y, year; S, salinity; IR, irrigation regime; C, cultivar; a,bvalues followed by different letters within columns are significantly different by SNK test, $\mathrm{P}<0.05$; ns, F test not significant; *F test significant at $\mathrm{P}<0.05$ and ${ }^{* * P} \mathrm{P}<0.01$.

The results of this research did not show any variation of optimal water depletion fraction in saline condition contrary to the literature information. In fact, the literature reported that the osmotic stress, due to the soil salinity, interferes with water availability and that optimal water depletion fraction in saline condition decreases and depends also on the crop yield characteristics (Allen et al., 1998) which is in agreement with the results obtained on artichoke crop at the same experimental site (Boari et al., 2012). The results of this trial demonstrate that tomato irrigated with saline water needs watering less fre- quently. Maximum water depletion fractions were $40 \%$ and $60 \%$ of total soil available water to preserve total and marketable yield, respectively.

\section{Conclusions}

The salt tolerance of tomato cultivar utilized in this trial resulted in agreement with that reported by Francois and Maas (1994). Salinity 
improved fruit quality, but caused blossom-end rot, and the cultivar mostly susceptible was $H L Y 19$ with elongated fruits.

The results of this work demonstrated that the thresholds of easily available water to preserve total and marketable yield of tomato crop were 40 and $60 \%$, respectively. These results are in disagreement with Allen et al. (1998) that stated a lower value of soil water depletion by increasing soil salinity, as a consequence of higher osmotic stress. Watering more frequently, instead, on the soil type of the trial, probably causes waterlogging and root hypoxia affecting negatively tomato yield. In fact, tomato is a species very sensitive to the soil hypoxia (Bray et al., 2001; Jackson et al., 2003; Ahsan et al., 2007; Vidoz et al., 2010). Therefore, the non-interaction between the salinity level and the watering regime can be attributed to the soil structure deterioration that happened by increasing salinity, that worsened further by watering more frequently. In fact, the most appropriate irrigation scheduling should be decided after the testing several solution with respect to the soil type, cultivar and environmental conditions.

Finally, it is worthwhile to point out that in W1 and W3 happened higher incidence of blossom-end rot that could be explained by i) temporary conditions of root asphyxia for W1, occurred because of frequent watering and water and nutritional imbalance; and ii) short periods of water stress due to greater allowable depletion and less frequent irrigation for W3.

\section{References}

Adams P, Ho LC, 1992. The susceptibility of modern tomato cultivars to blossom end rot in relation to salinity. J. Hortic. Sci. 67:827-839.

Adams P, Ho LC, 1993. Effects of environment on the uptake and distribution of calcium in tomato and on incidence of blossom-end rot. Plant Soil 154:127-132.

Adams P, Ho LC, 1995. Uptake and distribution of nutrients in relation to tomato fruit quality. Acta Hortic. 412: 374-387.

Ahsan N, Lee DG, Lee SH, Lee KW, Bahk JD, Lee BH, 2007. A proteomic screen and identification of waterlogging-regulated proteins in tomato roots. Plant Soil 295:31-57.

Allen RG, Pereira LS, Raes D, Smith M, 1998. Crop evapotranspiration. FAO Irrigation and Drainage Paper 56. FAO Publ., Roma, Italy.

Ancona V, Bruno DE, Lopez N, Pappagallo G, Uricchio VF, 2010. A modified soil quality index to assess the influence of soil degradation processes on desertification risk: the Apulia case. Ital. J. Agron. 5(Suppl.3):45-55.

Barret-Lennard G, 2003. The interaction between waterlogging and salinity in higher plants: causes, consequences and implications. Plant Soil 253:35-54.

Barrocu G, 2003. Seawater intrusion in the coastal aquifers of Italy. In: J. Calaferra (ed.) State of seawater intrusion in coastal aquifers of the Mediterranean Coast. SWIM-SWICA Publ., Alicante, Spain.

Belda R, Ho LC, 1993. Salinity effects on the network of vascular bundles during tomato fruit development. J. Hortic. Sci. 68:557-564.

Boari F, Pace B, Todorović M, De Palma E, Cantore V, 2012. Effect of water regime and salinity on artichoke yield. Ital. J. Agron. 7:e9.

Bray EA, Bailey-Serres J, Weretilnyk E, 2001. Responses to abiotic stresses. In: B.B. Buchanan, W. Gruissem and R.L. Jones (eds.) Biochemistry and molecular biology of plants. American Society of Plant Physiologist Publ., Rockville, MD, USA, pp 1158-1203.

Cantore V, Boari F, Pace B, 2008. Salinity effects on tomato. Proc. 15th EUCARPIA Tomato. Acta Hortic. 789:229-234.

Cantore V, Boari F, Stelluti M, De Palma E, 2001. Irrigazione del pomodoro con acqua salmastra in fasi fenologiche diverse. pp 139152 in Atti Convegno POM-OTRIS Palerm, Italy.

Cantore V, Iovino F, Pontecorvo G, 1987. Aspetti climatici e zone fitocli- matiche della Basilicata. C.N.R. IEIF-Cosenza, Grafiche Badiali s.n.c. Ed., Arezzo, Italy.

Capaccioni B, Didero M, Paletta C, Didero L, 2005. Saline intrusion and refreshening in a multilayer coastal aquifer in the Catania Plain (Sicily, Southern Italy): dynamics of degradation processes according to the hydrochemical characteristics of groundwater. J. Hydrol. 307:1-16.

Castrignanò A, de Caro A, Tarantino E, 1985. Verifica sulla validità di alcuni metodi empirici di stima dell'evapotraspirazione potenziale nel Metapontino. Irrigazione 32:23-28.

Cau P, Lecca G, Muscas L, Barrocu G, Uras G, 2002 Saltwater intrusion in the plain of Oristano (Sardinia). pp 435-444 in Proc. 17th Salt Water Intrusion Meet., Delft, The Netherlands.

Cotecchia V, Polemio M, 1997. Monitoraggio idrogeologico continuo per salvaguardare le acque sotterranee pugliesi. Dimensione Ricerca 2:11-15.

Cuartero J, Soria T, 1997. Productividad de tomates cultivados en condiciones salinas. Acta Hortic. 16:214-221.

Cucci G, Cantore V, Boari F, De Caro A, 2000. Water salinity and influence of SAR on yield and quality parameters in tomato. Acta Hortic. 537:663-670.

Ehret DL, Ho LC, 1986. The effects of salinity on dry matter partitioning and fruit growth in tomatoes grown in nutrient film culture. J. Hortic. Sci. 61:361-367.

Fisher RA, 1980. Influence of water stress on crop yield in semiarid regions. In: N.C. Turner and P.J. Kramer (eds.) Crop water requirements. INRA Publ., Paris, France, pp 221-234.

Flagella Z, Cantore V, Giuliani MM, Tarantino E, De Caro A, 2002. Crop salt tolerance: Physiological, yield and quality aspects. In: S.G. Pandalai (ed.) Recent Research Developments in Plant Biology, Vol. 2. Research Signpost ed., Kerala, India.

Francois LE, Maas EV, 1994. Crop response and management on saltaffected soils. In: M. Pessarakli (ed.) Handbook of plant and crop stress. M. Dekker Ed., New York, NY, USA, pp 149-181.

Gideon 0, DeMalach Y, Gillerman L, David I, Lurie S, 2002. Effect of water salinity and irrigation technology on yield and quality of pears. Biosyst. Eng. 81:237-247.

Grattan SR, Grieve CM, 1999. Salinity-mineral nutrient relations horticultural crops. Sci. Hortic. 78:127-157.

Ho LC, White PJ, 2005. A cellular hypothesis for the reduction of blossom-end rot in tomato fruit. Ann. Bot.-London 95:571-581.

Incerti A, Navari-Izzo F, Pardossi A, Mensuali A, Izzo R, 2007. Effect of sea water on biochemical properties of fruit of tomato (Lycopersicon esculentum Mill.) genotypes differing for ethylene production. J. Sci. Food Agr. 87:2528-2537.

Jackson MB, Saker LR, Crisp CM, Else MA, Janowiak F, 2003. Ionic and $\mathrm{pH}$ signalling from roots to shoots of flooded tomato plants in relation to stomatal closure. Plant Soil 253:103-113.

Katerji N, van Hoorn JW, Hamdy A, Mastrorilli M, 2003. Salinity effect on crop development and yield analysis of salt tolerance according to several classification methods. Agr. Water Manage. 62:37-66.

Maas EV, 1986. Salt tolerance of plants. Appl. Agric. Res. 1:12-26.

Maas EV, Hoffman GJ, 1977. Crop salt tolerance - current assessment. J. Irr. and Drain. Div.-ASCE 103:115-134.

Magàn JJ, Gallardo M, Thompson RB, Lorenzo P, 2008. Effects of salinity on fruit yield and quality of tomato grown in soil-less culture in greenhouses in Mediterranean climatic conditions. Agr. Water Manage. 95:1041-1055.

Max JFJ, Horst WJ, 2009. Influence of nighttime electrical conductivity of substrate solution on fruit cracking and blossom-end rot of greenhouse tomato in the tropics. J. Plant Nutr. Soil Sc. 172:829838.

Mizrahi Y, Pasternak D, 1985. Effect of salinity on quality of various agricultural crop. Plant Soil 89:301-307. 
Munns R, 2002. Comparative physiology of salt and water stress. Plant Cell Environ. 25:239-250.

Munns R, 2005. Genes and salt tolerance: bringing them together. New Phytol. 167:645-663.

Pereira LS, Cordery I, Iacovos I, 2009. Coping with water scarcity. Springer Ed., Dordrecht, The Netherlands.

Plaut Z, 1997. Irrigation with low-quality water: effects on productivity, fruit quality and physiological processes of vegetable crops. Acta Hortic. 449:591-597.

Polemio M, Limoni PP, 2001. L'evoluzione dell'inquinamento salino delle acque sotterranee della Murgia e del Salento. Mem. Soc. Geol. It. 56:327-331.

Rapti-Caputo D, 2010. Influence of climatic changes and human activities on the salinization process of coastal aquifer systems. Ital. J. Agron. 5(Suppl.3):67-79.

Rengasamy P, 2002. Transient salinity and subsoil constraints to dryland farming in Australian sodic soils: an overview. Aust. J. Exp. Agr. 42:351-361.

Rhoades JD, 1987. Use of saline water for irrigation. Water Qual. Bull. 12:14-20.

Rhoades JD, Kandiah A, Mashali AM, 1992. The use of saline waters for crop production. FAO Irrigation and Drainage Paper No. 48. FAO Publ., Roma, Italy.

Scheidleger A, Grath J, Lindinger H, 2004. Saltwater intrusion due to groundwater over-exploitation EEA inventory throughout Europe. Page 125 in Proc. 18th Saltwater Intrusion Meet., Cartagena, Spain.
Segura ML, Contreras JI, Salinas R, Lao MT, 2009. Influence of salinity and fertilization level on greenhouse tomato yield and quality. Commun. Soil Sci. Plan. 40:485-497.

Selvaggi R, Colonna N, Lupia F, Murgia MS, Poletti A, 2010. Water quality and soil natural salinity in the Southern Imera Basin (Sicily, Italy). Ital. J. Agron. 5(Suppl.3):81-89.

Shani U, Dudley LM, 2001. Field studies of crop response to water and salt stress. Soil Sci. Soc. Am. J. 65:1522-1528.

Sharaf AR, Hobson GE, 1986. Effect of salinity of normal and non-ripening mutant tomatoes. Acta Hortic. 190:175-181.

Tarantino E, Caliandro A, 1984. Water requirements and crop coefficients of different of different crop in Italy as related to the climatic characteristics and the growth stage. pp 291-304 in Proc. Int. Conf. on Crop water requirements, Paris, France.

van Ieperen W, 1996. Effects of different day and night salinity levels on vegetative growth, yield and quality of tomato. J. Hortic. Sci. 71:99111.

Vidoz ML, Loreti E, Mensuali A, Alpi A, Perata P, 2010. Hormonal interplay during adventitious root formation in flooded tomato plants. Plant J. 63:551-562.

Wu M, Kubota C, 2008. Effects of high electrical conductivity of nutrient solution and its application timing on lycopene, chlorophyll and sugar concentrations of hydroponic tomatoes during ripening. Sci. Hortic. 116:122-129.

Yeo AR, Lee KS, Izard P, Bourssier PJ, Flowers TJ, 1991. Short- and longterm effects of salinity on leaf growth in rice (Oryza sativa L.). J. Exp. Bot. 42:881-889. 